\title{
Effect of maize distillers dried grains with solubles and dietary enzyme supplementation on the performance of laying hens
}

\author{
S. Świątkiewicz ${ }^{1}$ and J. Koreleski \\ National Research Institute of Animal Production \\ Department of Animal Nutrition and Feed Science \\ 32-083 Balice, Poland
}

(Received 21 November 2005; revised version 9 January 2006; accepted 12 April 2006)

\begin{abstract}
In an experiment on 84 Lohman Brown hens (from 26 to 68 weeks of age), the effect of the different dietary levels of maize distillers dried grains with solubles (DDGS) on laying performance and egg quality was studied. Experimental diets were isocaloric and isonitrogenous and contained $0,5,10,15$ or $20 \%$ DDGS. The diet with $20 \%$ DDGS was also supplemented with NSP-hydrolizing enzymes or with enzymes and additional amounts of lysine and methionine.

In the first phase of the laying cycle (26-43 weeks of age) the dietary level of DDGS did not significantly affect the laying rate, daily weight of laid eggs, feed intake and feed conversion. In the second phase of the cycle (44-68 weeks of age), there were no differences in egg production parameters between groups fed diets with 0, 5, 10 and 15\% DDGS. A dietary level of $20 \%$ DDGS negatively affected laying rate and daily weight of eggs, however, addition of NSP-hydrolizing enzymes to the diet reduced in part this negative influence. The level of DDGS in the diet had no effect on albumen height, Haugh units, eggshell thickness, density and breaking, or sensory properties of boiled eggs. Yolk colour score significantly increased when DDGS was included in the diet.
\end{abstract}

KEY WORDS: maize DDGS, laying hens, laying performance, egg quality, yolk colour

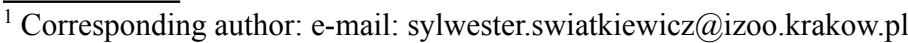




\section{INTRODUCTION}

Distillers dried grains with solubles (DDGS) is a by-product of ethanol production. Because of the high content of readily fermentable starch, maize is the main grain used in the fuel ethanol industry. During fermentation, approximately equal portions of ethanol, DDGS and $\mathrm{CO}_{2}$ are formed (Lumpkins et al., 2005). Because maize starch is converted to ethanol and $\mathrm{CO}_{2}$, the concentration of the remaining nutrients in DDGS increases 2-3-fold.

DDGS has been available as a feedstuff for many decades, but due to the relatively high level of fibre and variability in bioavailability of lysine and other nutrients, this ingredient has been traditionally fed mainly to ruminants. Early use of DDGS in poultry diets was primarily as a source of "unidentified growth factors" at low inclusion levels (Noll et al., 2001). In previous studies on laying hens it was shown that DDGS could be used at 5-20\% inclusion levels in diets, even as a source of one-third of the protein supply, without affecting performance (Matterson et al., 1966; Harms et al., 1969; Jensen et al., 1974) and had a positive effect on Haugh unit values (Jensen et al., 1978).

An increase of fuel ethanol production has been observed and has resulted in an enlarged quantity of DDGS entering the feed market in recent years. The high quality and low variability of nutrients in DDGS obtained from the modern ethanol industry is related to gentler drying conditions than in previous decades and allows the large-scale use of this ingredient in poultry nutrition also.

The objective of the experiment was to optimize the level of maize DDGS in the diet for laying hens and to study the effect of increasing levels of DDGS in diets on laying performance and egg quality. The possibility of improving the nutritional value of diets with high levels of DDGS by using NSP-hydrolizing enzymes and additional supplementation of diets with lysine and methionine was also evaluated.

\section{MATERIAL AND MEDHODS}

The experiment was carried out on 84 Lohman Brown laying hens from 26 to 68 weeks of age. Hens were randomly allocated to 7 experimental groups, each containing 12 layers, individually caged on a wire-mesh floor. Cages were $40 \mathrm{~cm}$ wide and $40 \mathrm{~cm}$ deep. During the experiment hens were offered water and feed $\mathrm{ad}$ libitum and were exposed to a $14 \mathrm{~L}: 10 \mathrm{D}$ lighting schedule, with the dark period at night.

The experimental diets were isocaloric and isonitrogenous and contained different levels $(0,5,10,15$ or $20 \%)$ of maize DDGS. The diet with the highest 
level of DDGS was also supplemented with NSP-hydrolizing enzymes or simultaneously with enzymes and additional amounts of crystalline lysine and methionine (Table 1).

Table 1. Composition and nutrient content of experimental diets diet, $\mathrm{g} \cdot \mathrm{kg}^{-1}$

\begin{tabular}{|c|c|c|c|c|c|c|c|}
\hline \multirow{2}{*}{ Item } & \multirow{2}{*}{$\begin{array}{l}\text { Control } \\
\text { I }\end{array}$} & \multicolumn{6}{|c|}{ Diets with maize DDGS } \\
\hline & & II & III & IV & $\mathrm{V}$ & VI & VII \\
\hline \multicolumn{8}{|l|}{ Ingredients } \\
\hline maize & 350 & 300 & 290 & 260 & 250 & 250 & 250 \\
\hline wheat & 244.9 & 284.5 & 284.6 & 304 & 298.2 & 298.2 & 296 \\
\hline soyabean meal & 230 & 190 & 150 & 110 & 75 & 75 & 75 \\
\hline maize DDGS & - & 50 & 100 & 150 & 200 & 200 & 200 \\
\hline grass meal & 30 & 30 & 30 & 30 & 30 & 30 & 30 \\
\hline rapeseed oil & 33 & 33 & 32 & 32 & 32 & 32 & 32 \\
\hline limestone & 89 & 89 & 89 & 89 & 89 & 89 & 89 \\
\hline dicalcium phosphate & 14 & 14 & 14 & 14 & 14 & 14 & 14 \\
\hline $\mathrm{NaCl}$ & 3 & 3 & 3 & 3 & 3 & 3 & 3 \\
\hline L-Lysine (78\%) & - & 0.5 & 1.5 & 2.3 & 3.2 & 3.2 & 4.8 \\
\hline DL-Methionine (99\%) & 1.1 & 1 & 0.9 & 0.7 & 0.6 & 0.6 & 1.2 \\
\hline vitamin-mineral premix ${ }^{1}$ & 5 & 5 & 5 & 5 & 5 & 5 & 5 \\
\hline NSP-hydrolizing enzymes ${ }^{2}$ & - & - & - & - & - & + & + \\
\hline \multicolumn{8}{|l|}{ Calculated } \\
\hline $\begin{array}{l}\text { metabolizable energy, } \\
\mathrm{MJ} \cdot \mathrm{kg}^{-13}\end{array}$ & \multicolumn{6}{|c|}{11.45} & 11.45 \\
\hline crude protein 4 & \multicolumn{6}{|c|}{170} & 170 \\
\hline Lys $^{4}$ & \multicolumn{6}{|c|}{7.80} & 9.00 \\
\hline $\mathrm{Met}^{4}$ & \multicolumn{6}{|c|}{3.70} & 4.30 \\
\hline $\mathrm{Ca}^{4}$ & \multicolumn{6}{|c|}{36.0} & 36.0 \\
\hline total $\mathrm{P}^{4}$ & \multicolumn{6}{|l|}{6.10} & 6.10 \\
\hline \multicolumn{8}{|c|}{$\begin{array}{l}{ }^{1} \text { Lutamix BASF, supplied to } 1 \mathrm{~kg} \text { of diet: IU: vit. A } 10000 ; \text { vit. } \mathrm{D}_{3} 3000 ; \mathrm{mg}: \mathrm{K}_{3} 2 ; \mathrm{B}_{1} 1 ; \mathrm{B}_{2} 4 \text {; } \\
\mathrm{B}_{6} 1.5 ; \mathrm{B}_{12} 0.01 \text {; Ca-pantotenate } 8 \text {; niacine } 25 ; \text { folic acid } 0.5 ; \text { choline-Cl } 250 ; \mathrm{Mn} 100 ; \mathrm{Zn} 50 ; \mathrm{Fe} \\
50 ; \mathrm{Cu} 8 ; \mathrm{J} 0.8 \text {; Se } 0.2 \text { and } \mathrm{Co} 0.2\end{array}$} \\
\hline \multicolumn{8}{|c|}{$\begin{array}{l}{ }^{2} \text { Ronozyme WX (endo-1,4- } \beta \text {-xylanase activity of } 1000 \mathrm{FSU} / \mathrm{g} \text { ) and Ronozyme VP (endo-1,3(4) } \\
\text { - } \beta \text {-glucanase activity of } 50 \mathrm{FBG} / \mathrm{g} \text { and also pentozanase, hemicellulase and pectinase activity). } \\
\text { Each preparation was added to the diet in amount of } 200 \mathrm{mg} \cdot \mathrm{kg}^{-1}\end{array}$} \\
\hline \multicolumn{8}{|c|}{${ }^{3}$ calculated according to European Table (1989) as a sum of ME content of components } \\
\hline \multicolumn{8}{|c|}{$\begin{array}{l}4 \text { calculated according to the chemical composition of feed components. Chemical composition of maize } \\
\text { DDG used in the experiment calculated according to European Table (1989), was: g/kg: dry matter } \\
926 \text {; crude protein } 353 \text {; crude fat } 38.9 \text {; crude fibre } 108 \text {; crude ash } 16.9 \text {; lysine } 6.40 \text {; methionine } 6.20 \text {; } \\
\text { cystine } 6.57 \text {; calcium } 0.83 \text {; phosphorus } 5.43 \text {, sodium } 0.052 \text {; metabolizable energy, } \mathrm{MJ}^{-1} \mathrm{~kg}^{-1} 10.85\end{array}$} \\
\hline
\end{tabular}

The nutrient content of the diets was calculated according to the chemical composition of raw feedstuffs, metabolizable energy value, according to equations from European Tables (1989). The chemical composition of DDGS and other 
feed components was determined by conventional methods (AOAC, 1990). Amino acids were analysed in acid hydrolysates, sulphur amino acids, after initial peroxidation in the colour reaction with the ninhydrin reagent using a BeckmanSystem Gold 126 AA automatic analyser. The calcium content was determined by flame atomic absorption spectrophotometry, while phosphorus content, by a calorimetric method (AOAC, 1990).

During the experiment, feed intake, number and weight of laid eggs were registered and laying performance, daily feed intake and feed conversion per $\mathrm{kg}$ of eggs and per egg were calculated. At 32, 48 and 66 weeks of age, one egg from each hen was collected to determine quality using an Egg Quality Measurement apparatus (Micro version 3.2, 1990). Another egg was collected for measurement of shell breaking strength (using an Instron 5542 apparatus with constant head speed - $10 \mathrm{~N} / \mathrm{min}$ ).

At the end of the experiment ( 68 weeks of age), one egg from each hen from groups I, III, IV and V was collected for evaluation of sensory parameters. After 10-min boiling the eggs were evaluated by a six-member panel. Panelists ranked flavour and taste of eggs on a 4-point scale (2 - unacceptable, 3 - acceptable, 4 - good, 5 - very good).

Data were subjected to one-way analysis of variance. The significance of differences between means was determined by Duncan's multiple range test with use of the Statistica 5.0 PL software package.

\section{RESULTS AND DISCUSSION}

The chemical composition of DDGS is shown in Table 1. DDGS was characterized by a relatively high level of protein and fibre and low level of fat, ash, lysine, phosphorus and sodium as compared with literature data (Cromwell et al., 1993; Raw Material Compendium, 1994; Spiehs et al., 2002; Tables of DDGS Composition, 2005). Belyea et al. (2004) stated that high variation in composition of different samples of DDGS is not related to maize composition but rather to variations in processing techniques. Great variability in chemical composition of maize DDGS was also found by Cromwell et al. (1993). Spiehs et al. (2002) noted high variability in total lysine, methionine and minerals, but much lower in protein, fat and fibre levels among different sources of DDGS.

In the first phase of the laying cycle (26-43 weeks of age), the level of inclusion of DDGS in the diet had no effect on laying rate, daily weight of eggs, feed intake or feed conversion (Table 2). Similar results were observed by Lumpkins et al. (2005), who found no significant differences in egg production parameters between hens fed a commercial diet with 0 or $15 \%$ of maize DDGS. Also, in 
earlier research (Matterson et al., 1966) no effect of 10 or $20 \%$ maize DDGS in the diet was found on laying performance.

In the second phase of the laying cycle (44-68 weeks of age), there were no differences in laying performance between hens fed 0, 5, 10 and 15\% DDGS, but the use of $20 \%$ DDGS negatively affected $(\mathrm{P} \leq 0.05)$ laying rate and daily weight of eggs (Table 2). Roberson et al. (2005) fed Hy Line layers (47-67 weeks of age) with diets containing $0,5,10$ or $15 \%$ maize DDGS. They found no differences in egg production parameters at most ages, but at 52-53 weeks of age, the laying rate decreased linearly as DDGS was increased in the diet.

Table 2. Effect of maize DDGS on laying performance

\begin{tabular}{|c|c|c|c|c|c|c|c|c|}
\hline \multirow{3}{*}{ Item } & \multicolumn{7}{|c|}{ Dietary treatment } & \\
\hline & \multicolumn{7}{|c|}{ DDGS level, $\mathrm{g} / \mathrm{kg}$ diet } & \\
\hline & 0 & 50 & 100 & 150 & 200 & $\begin{array}{r}200 \\
+\mathrm{E}^{1} \\
\end{array}$ & $\begin{array}{c}200 \\
+\mathrm{E}+\mathrm{AA}^{2} \\
\end{array}$ & \\
\hline \multicolumn{9}{|c|}{ First phase of laying cycle (26-43 weeks of age) } \\
\hline laying rate, $\%$ & 98.1 & 97.7 & 97.7 & 98.2 & 97.6 & 97.7 & 97.7 & 0.16 \\
\hline daily $m$ & 59.8 & 60.2 & 59.7 & 59.9 & 59.3 & 60.0 & 59.5 & 0.19 \\
\hline daily $f$ & 114 & 115 & 114 & 115 & 115 & 114 & 113 & 0.22 \\
\hline feed & 116 & 117 & 117 & 117 & 118 & 117 & 116 & 0.25 \\
\hline feed, $\mathrm{kg}$ per 1 & 1.91 & 1.90 & 1.91 & 1.92 & 1.94 & 1.91 & 1.91 & 0.00 \\
\hline \multicolumn{9}{|c|}{ Second phase of laying cycle (44-68 weeks of age) } \\
\hline laying rate, $\%$ & $89.1^{\mathrm{b}}$ & $89.4^{\mathrm{b}}$ & $88.1^{\text {ab }}$ & $89.8^{\mathrm{b}}$ & $84.7^{\mathrm{a}}$ & $87.9^{\mathrm{ab}}$ & $87.9^{\mathrm{ab}}$ & 0.55 \\
\hline daily $n$ & $54.2^{\mathrm{ab}}$ & $55.5^{\mathrm{b}}$ & $54.1^{\mathrm{ab}}$ & $55.6^{\mathrm{b}}$ & $52.1^{\mathrm{a}}$ & $53.9^{\mathrm{ab}}$ & $53.7^{\mathrm{ab}}$ & 0.38 \\
\hline daily $\mathrm{f}$ & 115 & 116 & 114 & 115 & 114 & 114 & 114 & 0.31 \\
\hline feed, & 129 & 129 & 130 & 128 & 135 & 130 & 130 & 0.82 \\
\hline feed, $\mathrm{kg}$ per $1 \mathrm{~kg}$ of eggs & 2.12 & 2.08 & 2.11 & 2.07 & 2.19 & 2.11 & 2.12 & 0.01 \\
\hline \multicolumn{9}{|c|}{ Whole laying cycle (26-68 weeks of age) } \\
\hline & 92.7 & 92.8 & 92.0 & 93.2 & 90.0 & 91.9 & 91.9 & 0.36 \\
\hline daily $\mathrm{r}$ & 56.5 & 57.4 & 56.4 & 57.3 & 55.0 & 56.4 & 56.0 & 0.25 \\
\hline daily $\mathrm{f}$ & 115 & 115 & 114 & 115 & 115 & 114 & 114 & 0.20 \\
\hline feed, kg per 1 egg & 124 & 124 & 124 & 123 & 127 & 124 & 124 & 0.50 \\
\hline feed, $\mathrm{kg}$ per $1 \mathrm{~kg}$ of eggs & 2.03 & 2.01 & 2.02 & 2.01 & 2.08 & 2.02 & 2.03 & 0.009 \\
\hline
\end{tabular}

${ }^{1}$ supplemented with enzyme - see Table 1

${ }^{2}$ supplemented with enzyme, lysine and methionine - see Table 1

${ }^{\mathrm{a}, \mathrm{b}}$ means in rows with different letters differ significantly at $\mathrm{P} \leq 0.05$

Supplementation of the $20 \%$ DDGS diet with NSP-hydrolizing enzymes ameliorated in part the decrease in egg performance observed in the second phase of the laying cycle (Table 2). This could suggest that the high content of non-starch polysaccharides is one of the reasons for the negative effect of the $20 \%$ DDGS diet. Addition of enzymes to poultry diets with a high level of water-soluble NSP 
reduces the viscosity of the intestinal content and improves nutrient absorption (Bedford and Morgan, 1996). The positive effect of enzyme supplementation of hen diets containing cereals rich in NSP on performance was observed among others by Szczurek et al. (1997), Pan et al. (1998) and Lazaro et al. (2003).

In our experiment supplementation of the diet containing 20\% DDGS, $0.78 \%$ total lysine and $0.37 \%$ methionine with an additional amount of these amino acids had no beneficial influence on laying performance (Table 2). These results indicate that the availability of amino acids in DDGS from the modern ethanol industry is relatively high and is not a limiting factor in the use of DDGS for poultry. Similarly Lumpkins and Batal (2005) stated that lysine digestibility of DDGS from modern ethanol plants is high $(75-80 \%)$ and is not hindered during the drying process. In an experiment on caecectomized roosters, Ergul et al. (2003) determined the amino acid digestibility of DDGS from different sources. Lysine digestibility averaged $71 \%$, but variability of this parameter was high. Lysine digestibility of high quality DDGS (lightly coloured) was about $80 \%$, of poor quality DDGS (dark coloured), about $60 \%$. Methionine variability among samples was low and its digestibility averaged $88 \%$. Our results do not agree with the results of early work of Jensen et al. (1974) who found a positive effect on laying rate of adding $0.025 \%$ lysine to hen diets containing $10 \%$ DDGS and $0.73 \%$ total lysine.

The inclusion level of DDGS had no effect on egg quality parameters: albumen height, Haugh units and egg shell thickness, density and breaking strength (Table 3). Similar results were obtained by Lumpkins et al. (2005) and Roberson and al. (2005). Previous work done by Jensen et al. (1978) showed no effect of a $10 \%$

Table 3. Effect of maize DDGS on internal and external quality and sensoric properties of eggs

\begin{tabular}{|c|c|c|c|c|c|c|c|c|}
\hline \multirow{3}{*}{ Item } & \multicolumn{7}{|c|}{ Dietary treatment } & \multirow{3}{*}{ SEM } \\
\hline & \multicolumn{7}{|c|}{ DDGS level, $\mathrm{g} / \mathrm{kg}$ diet } & \\
\hline & 0 & 50 & 100 & 150 & 200 & $\begin{array}{r}200 \\
+E^{1} \\
\end{array}$ & $\begin{array}{c}200 \\
+\mathrm{E}+\mathrm{AA}^{2}\end{array}$ & \\
\hline Albumen height, $\mathrm{mm}^{3}$ & 5.83 & 5.66 & 5.89 & 6.09 & 5.88 & 5.91 & 6.12 & 0.088 \\
\hline Haugh units ${ }^{3}$ & 73.9 & 72.1 & 75.7 & 76.8 & 75.5 & 76.4 & 77.7 & 0.65 \\
\hline Yolk colour, points in Roche scale & $4.67^{\mathrm{a}}$ & $5.22^{\mathrm{b}}$ & $5.48^{\mathrm{b}}$ & $6.15^{\mathrm{c}}$ & $6.04^{\mathrm{c}}$ & $6.45^{\mathrm{c}}$ & $6.20^{\mathrm{c}}$ & 0.093 \\
\hline Eggshell thickness, $\mu \mathrm{m}^{3}$ & 372 & 378 & 378 & 371 & 377 & 365 & 373 & 2.17 \\
\hline Eggshell density, $\mathrm{mg} \cdot \mathrm{cm}^{2-13}$ & 88.3 & 90.3 & 89.8 & 88.9 & 88.4 & 89.5 & 90.7 & 0.59 \\
\hline Eggshell breaking strength, $\mathrm{N}^{3}$ & 41.9 & 42.1 & 42.5 & 41.8 & 42.2 & 41.7 & 41.7 & 0.41 \\
\hline Flavour of boiled eggs, points & 4.33 & 4.33 & 4.17 & 4.25 & 4.33 & $n e^{4}$ & $n e^{4}$ & 0.06 \\
\hline Taste of boiled eggs, points & 4.25 & 4.33 & 4.25 & 4.25 & 4.50 & $n e^{4}$ & $\mathrm{ne}^{4}$ & 0.06 \\
\hline
\end{tabular}

\footnotetext{
${ }^{1}$ supplemented with enzyme - see Table 1

${ }^{2}$ supplemented with enzyme, lysine and methionine - see Table 1

${ }^{3}$ average value from three analysis (at 32, 48 and 66 weeks of age)

${ }^{4}$ in groups VI and VII flavour and taste of boiled eggs were not evaluated (ne)

${ }_{a, b, c}$ means in rows with different letters differ significantly at $\mathrm{P} \leq 0.05$
} 
DDGS diet on shell thickness and shell breaking strength, but DDGS positively affected interior egg quality measured as Haugh units.

Eggs of hens fed the diet with DDGS had a higher yolk colour score and even $5 \%$ DDGS was sufficient to improve this parameter (Table 3). This indicates that carotenoids in the DDGS used in the study were highly available. Roberson et al. (2005) noted that yolk colour increased quickly with a 10\% DDGS diet and by two months with 5\% DDGS diet. In contrast, Lumpkins et al. (2005) found no effects of an experimental diet with $15 \%$ maize DDGS on this parameter.

In our study all evaluated eggs were characterized by good flavour and taste, the level of DDGS in the diet had no adverse effect on the sensory properties of eggs (Table 3 ).

\section{CONCLUSIONS}

The results of this study indicate that maize DDGS is a useful feed ingredient for laying hens. It could be included to the diet up to $15 \%$ without negative effects on laying performance and egg quality. In the second phase of laying, 20\% DDGS in the diet decreased egg production parameters, but addition of NSP-hydrolizing enzymes partly ameliorated this negative influence.

\section{REFERENCES}

AOAC, 1990. Official Methods of Analysis, Association of Official Analytical Chemists. $15^{\text {th }}$ Edition. Arlington, VA

Bedford M.R., Morgan A.J., 1996. The use of enzymes in poultry diets. World Poultry Sci. J. 52, 61-68

Belyea B.L., Rausch K.D., Tumbleson M.E., 2004. Composition of corn and distillers dried grains with solubles from dry grind ethanol processing. Bioresource Technol. 94, 293-298

Cromwell G.L., Herkelman K.L., Stahly T.S., 1993. Physical, chemical, and nutritional characteristics of distillers dried grains with solubles for chicks and pigs. J. Anim. Sci. 71, 679-686

Ergul T., Martinez Amezcua C., Parsons C.M., Walters B., Brannon J., Noll S.L., 2003. Amino acid digestibility in corn distillers dried grains with solubles. Poultry Sci. 82, Suppl. 1, 70 (Abstr.)

European Table of Energy Values for Poultry Feedstuffs, 1989. WPSA, Wageningen

Harms R.H., Moreno S., Damron B.L., 1969. Evaluation of distillers dried grains with solubles in diets of laying hens. Poultry Sci. 48, 1652-1655

Jensen L.S., Chang C.H., Wilson L.P., 1974. Effect of distillers dried grains with solubles on reproduction and liver fat accumulation in laying hens. Poultry Sci. 53, 586-592

Jensen L.S., Chang C.H., Wilson L.P., 1978. Interior egg quality: improvement by distillers feeds and trace elements. Poultry Sci. 57, 548-654

Lazaro R., Garcia M., Aranibar M.J., Mateos G.G., 2003. Effect of enzyme addition to wheat-, barley- and rye-based diets on nutrient digestibility and performance of laying hens. Brit. Poultry Sci. 44, 256-265

Lumpkins B., Batal A., 2005. The bioavailability of lysine and phosphorus in distillers dried grains with solubles. Poultry Sci. 84, 581-586 
Lumpkins B., Batal A., Dale N., 2005. Use of distillers dried grains plus solubles in laying hen diets. J. Appl. Poultry Res. 14, 25-31

Matterson L.D., Tlustohowicz J., Singsen E.P., 1966. Corn distillers dried grains with solubles in rations for high-producing hens. Poultry Sci. 45, 147-151

Noll S., Stangeland V., Speers G., Brannon J., 2001. Distillers grains in poultry diets. Proceedings of $62^{\text {nd }}$ Minnesota Nutrition Conference and Minnesota Corn Growers Association Technical Symposium, Bloomington, pp. 11-12

Pan C.F., Igbasan F.A., Guenter W., Marquardt R.R., 1998. The effects of enzyme and phosphorus supplements in wheat- and rye-based diets on laying hen performance, energy and phosphorus availability. Poultry Sci. 77, 83-89

Raw Material Compendium, a Compilation of Worldwide Data Sources, 1994. Novus International, Inc. $2^{\text {nd }}$ Edition

Roberson K.D., Kalbfleisch J.L., Pan W., Charbenau R.A., 2005. Effect of corn distiller's dried grains with solubles at various levels on performance of laying hens and egg yolk color. Int. J. Poultry Sci. 4, 44-51

Spiehs M.J., Whitney M.H., Shurson G.C., 2002. Nutrient database for distiller's dried grains with solubles produced from new ethanol plants in Minnesota and South Dakota. J. Anim. Sci. 80, 2639-2645

Szczurek W., Koreleski J., Kuchta M., 1997. Non-starch polysaccharides degrading enzymes in feeds improve performance of laying hens (in Polish). Rocz. Nauk. Zoot. 24, 205-220

Tables of DDGS Composition, 2005. http://www.ddgs.umn.edu/nutrientprofiles.htm 